\title{
Chromatin states of developmentally-regulated genes revealed by DNA and histone methylation patterns in zebrafish embryos
}

\author{
LEIF C. LINDEMAN ${ }^{1}$, CECILIA L. WINATA2 ${ }^{2}$, HÅVARD AANES ${ }^{3}$, SINNAKARUPPAN MATHAVAN², \\ PETER ALESTRÖM ${ }^{3}$ and PHILIPPE COLLAS*,1

\begin{abstract}
1 Institute of Basic Medical Sciences, Faculty of Medicine, University of Oslo, and Norwegian Center for Stem Cell Research, Oslo, Norway, ${ }^{2}$ Stem Cell and Developmental Biology, Genome Institute of Singapore, Biopolis, Singapore and ${ }^{3}$ BasAM, Norwegian School of Veterinary Science, Oslo, Norway
\end{abstract}

\begin{abstract}
Embryo development proceeds from a cascade of gene activation and repression events controlled by epigenetic modifications of DNA and histones. Little is known about epigenetic states in the developing zebrafish, despite its importance as a model organism. We report here DNA methylation and histone modification profiles of promoters of developmentallyregulated genes (pou5f1, sox2, sox3, klf4, nnr, otx1b, nes, vasa), as well as tert and bactin2, in zebrafish embryos at the mid-late blastula transition, shortly after embryonic genome activation. We identify four classes of promoters based on the following profiles: (i) those enriched in marks of active genes (H3K9ac, H4ac, $\mathrm{H} 3 \mathrm{~K} 4 \mathrm{me} 3$ ) without transcriptionally repressing $\mathrm{H} 3 \mathrm{~K} 9 \mathrm{me} 3$ or H3K27me3; (ii) those enriched in H3K9ac, H4ac and H3K27me3, without H3K9me3; one such gene was klf4, shown by in situ hybridization to be mosaically expressed, likely accounting for the detection of both activating and repressive marks on its promoter; (iii) those enriched in H3K4me3 and H3K27me3 without acetylation; and (iv) those enriched in all histone modifications examined. Culture of embryo-derived cells under differentiation conditions leads to $\mathrm{H} 3 \mathrm{~K} 9$ and $\mathrm{H} 4$ deacetylation and H3K9 and H3K27 trimethylation on genes that are inactivated, yielding an epigenetic profile similar to those of fibroblasts or muscle. All promoters however retain H3K4me3, indicating an uncoupling of H3K4me3 occupancy and gene expression. All non-CpG island developmentallyregulated promoters are DNA unmethylated in embryos, but hypermethylated in fibroblasts. Our results suggest that differentially expressed embryonic genes are regulated by various patterns of histone modifications on unmethylated DNA, which create a developmentally permissive chromatin state.
\end{abstract}

KEY WORDS: Danio rerio, DNA methylation, embryo, gene expression, histone modification, zebrafish

\section{Introduction}

Vertebrate embryo development proceeds from a cascade of gene activation and repression events in response to extracellular signals and local determinants. These transcriptional changes result from a pre-determined differentiation program and regulate differentiation. Within the embryo, coordination of transcription in specific blastomeres requires intricate gene regulatory networks (Levine and Davidson, 2005; Chan et al., 2009; Morley et al., 2009).
Binding of transcriptional regulators to specific genomic sites, the raison d'être of gene regulatory networks, is itself modulated by modifications of DNA and chromatin. Among these, methyla-

\footnotetext{
Abbreviations used in this paper: ac, acetylated; ChIP, chromatin immunoprecipitation; MBT, mid-blastula transition; MBT+, mid-late blastula transition; me3, trimethylated; PTM, post-translational modification; RTPCR, reverse transcription polymerase chain reaction; qPCR, quantitative PCR; TSS, transcription start site.
}

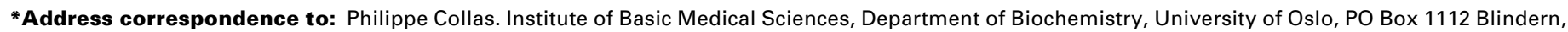
0317 Oslo, Norway. Tel: +47-22851066. Fax: +47-22851058. e-mail: philippe.collas@medisin.uio.no - Web: www.collaslab.com 
tion of cytosines within CpG dinucleotides is generally associated with gene repression, notably during development and differentiation (Jaenisch and Bird, 2003). In addition, post-translational modifications (PTMs) of core histones modulate their interaction with nucleosomal DNA and targeting of transcriptional regulators (Kouzarides, 2007). In particular, trimethylation of lysine (K) 9 of histone $\mathrm{H} 3$ (H3K9me3) marks promoters of inactive genes in a heterochromatin context. Temporarily inactive genes, such as in undifferentiated cells, are marked by H3K27me3, a mark of facultative heterochromatin, with or without the transcriptionally permissive H3K4me3 (Azuara et al., 2006; Bernstein et al., 2006; Cui et al., 2009). In contrast, promoters of active genes are associated with $\mathrm{H} 3 \mathrm{~K} 4 \mathrm{me} 3$ and acetylated $\mathrm{H} 3 \mathrm{~K} 9$ (H3K9ac) or $\mathrm{H} 4$. Little is known on histone PTMs associated with developmentallyregulated genes in embryos, and only recently have histone PTM mapping data emerged in the mouse embryo (O'Neill et al., 2006;

\section{A}

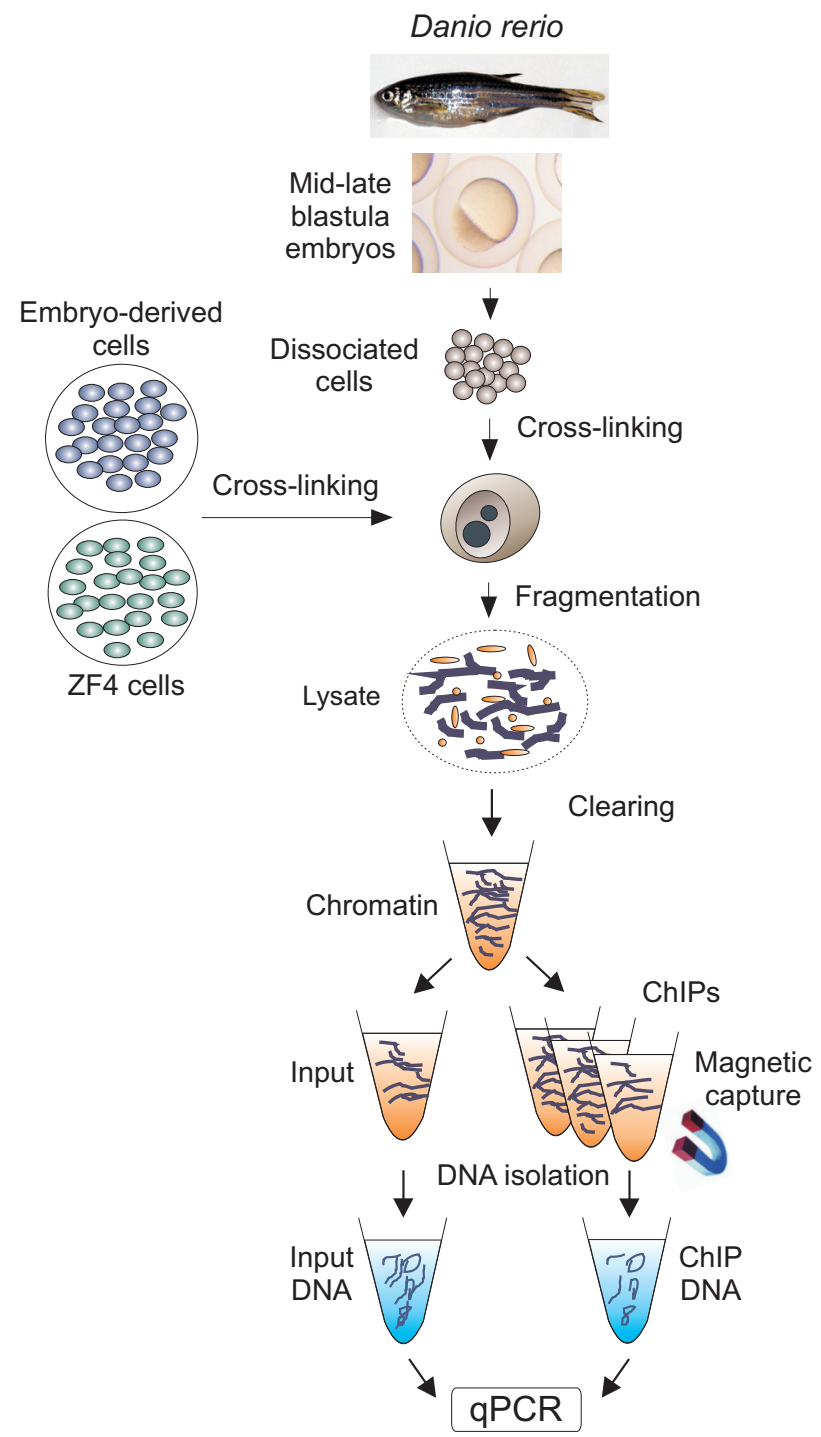

Vermilyea et al., 2009; Dahl et al., 2010).

Despite the importance of zebrafish (Danio rerio) as a model organism for studying vertebrate embryogenesis (Aleström et al., 2006) and developmental regulatory networks (Chan et al., 2009), little is known on histone PTMs associated with developmentallyregulated genes in this organism. In zebrafish, chromatin immunoprecipitation (ChIP) (Collas and Dahl, 2008) has been used to investigate the association of $\mathrm{H} 4 \mathrm{ac}$ and $\mathrm{C}-\mathrm{Myc}$ on specific promoters (Havis et al., 2006), map H3K4me3 sites in gastrula-stage embryos (Wardle et al., 2006) and investigate the role of specific transcription factors in hematopoiesis (Hart et al., 2007). Of note, these ChIP protocols relied on protease treatment of embryos to remove the chorion prior to isolating chromatin. By re-assessing each step of the ChIP assay, we recently reported that proteases are detrimental to ChIP efficiency in zebrafish embryos, and subsequently improved the procedure (Lindeman et al., 2009).

B
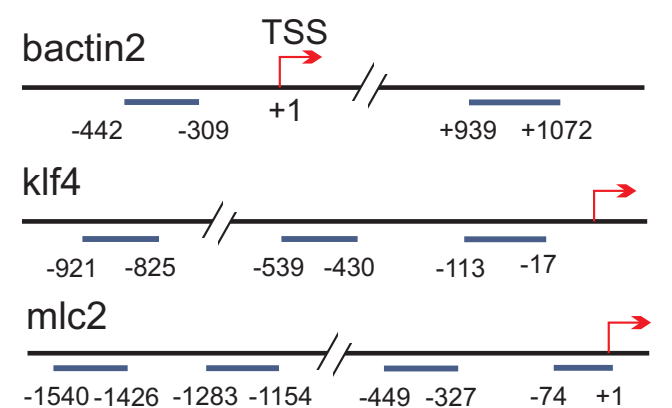

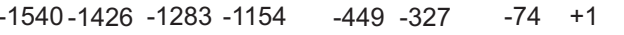
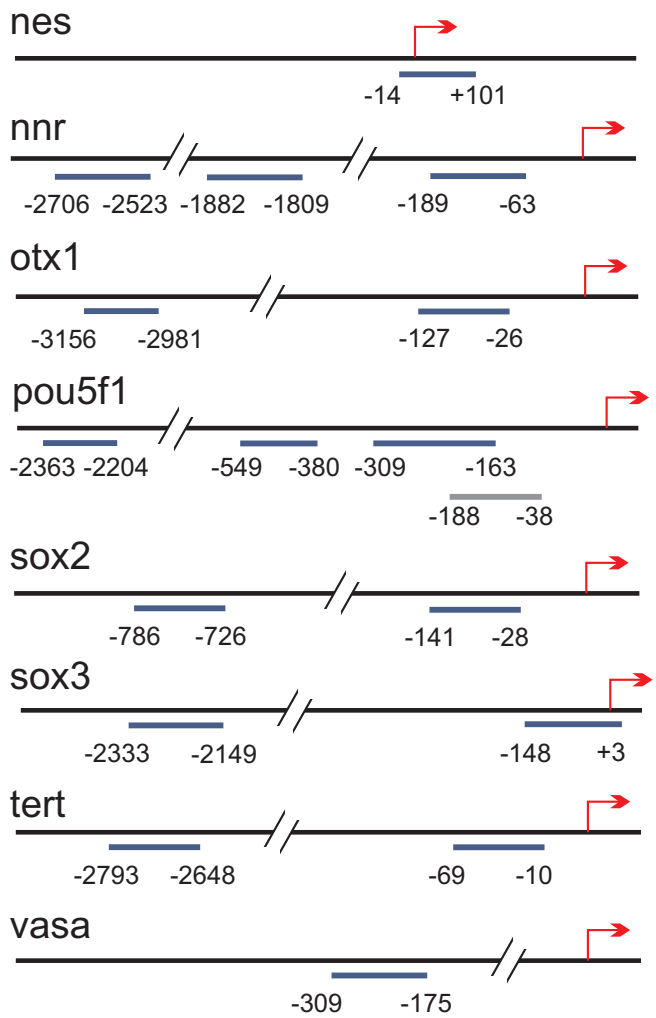

Fig. 1. Chromatin immunoprecipitation (ChIP) assay and map of genomic regions examined in this study. (A) Post-translational histone modifications in $\mathrm{MBT}^{+}$stage embryos, ZF4 cells and MBT+ embryo-derived cultured cells were examined by ChIP-qPCR. (B) Genomic regions examined by ChIP on indicated genes. Numbers indicate the position of amplicons relative to the TSS (+1). 
A

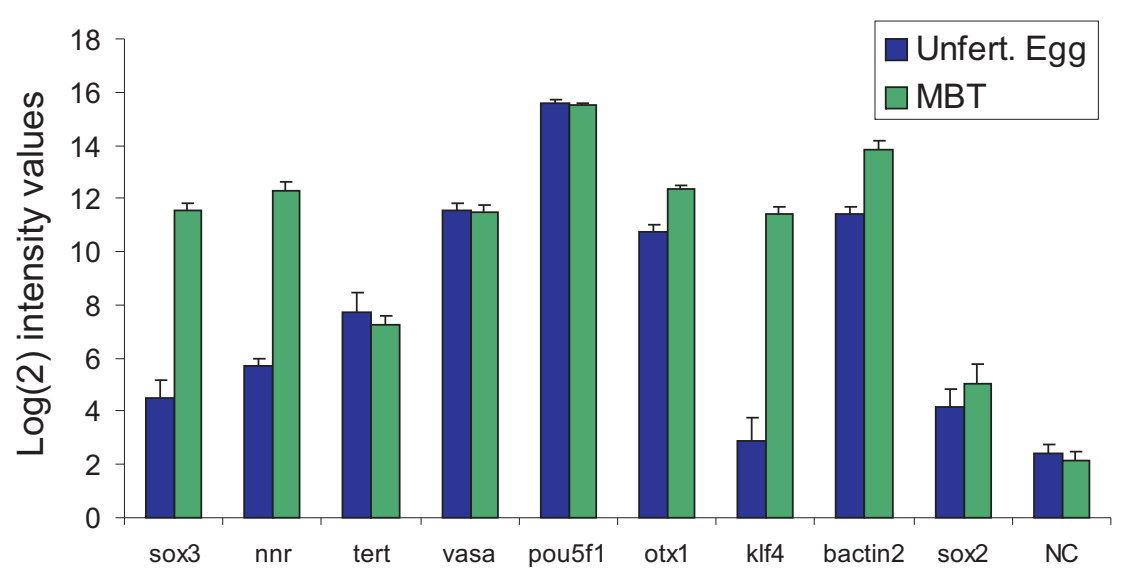

B

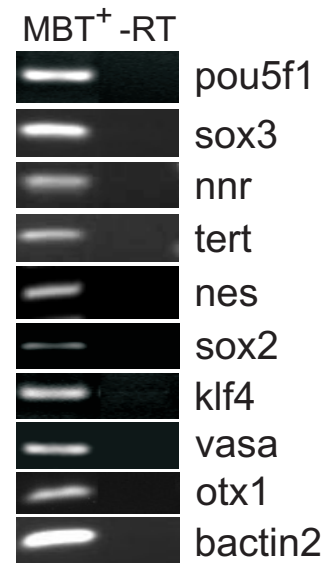

Fig. 2. Expression pattern of selected genes in zebrafish embryos. (A) Data extracted from Agilent microarray analyses of gene expression in unfertilized eggs and MBT embryos. Data was generated from 3 biological replicates for both stages, with 3 and 4 arrays for unfertilized egg and MBT stages, respectively. Signals were quantile-normalized, multiple probes for each gene were aggregated using the median, and mean $\pm S D$ calculated based on $\log _{2}$-transformed values. Negative controls are the mean of the replicates of the median of 150 different negative control probes scattered throughout the array. (B) RT-PCR analysis of expression of indicated genes in MBT+ embryos; -RT, PCR without reverse transcription.

We define here DNA methylation patterns at single-nucleotide resolution, and the occupancy of transcriptionally activating and repressing histone PTMs on the promoters of several developmentally-regulated genes in $A B$ strain zebrafish embryos at the mid-late blastula transition (3.5 $\mathrm{h}$ post-fertilization), shortly after embryonic gene activation. Our results reveal complex epigenetic patterns at this critical developmental time point. These do not necessarily correlate with promoter activity but are suggestive of a developmentally permissive chromatin state.

\section{Results}

Gene-specific post-translational histone modifications in embryos at the mid-late blastula transition

Aiming at understanding epigenetic states during zebrafish development, we recently optimized a ChIP assay for zebrafish embryos, resulting in minimal chromatin loss and epitope degradation (Lindeman et al., 2009). We applied this ChIP assay to determine histone PTM enrichment profiles on the promoters of a subset of developmentally-regulated genes in embryos at the mid-late blastula transition (referred to as $\mathrm{MBT}^{+}$), i.e. minutes after activation of the embryonic genome (Fig. 1A). The genes included pou5f1 (Pou-domain class 5 transcription factor 1, formerly named pou2 and also called oct4; GenBank accession number NM_131112), sox2 (SRY-box containing gene 2, NM_213118) and sox3 (SRY-box containing gene 3, NM_001001811) - two members of the SRY-related high-mobility group box family of transcription factors implicated in cell fate, klf4 (Krüppel-like factor 4, NM_131723; a Krüppel-like family transcription factor with a role in cell proliferation and differentiation), nnr (nanor; NM_001029947; a gene with a potential role in transcriptional regulation), vasa (NM_131057; a maternally-expressed gene with a role in germplasm formation) and otx $1 b$ (orthodenticle homolog 1b, NM_131250; encoding a bicoid sub- family homeodomain-containing transcription factor involved in brain development). We also examined tert (telomerase; NM_001083866), nes (nestin; XM_001919887; an early neuronal marker) and the ubiquitously expressed gene bactin2 (beta-actin 2; NM_181601). Promoter areas examined by ChIP are shown in Fig. 1B. Histone PTMs examined were three modifications associated with transcriptionally active genes (H3K9ac, H4ac and $\mathrm{H} 3 \mathrm{~K} 4 \mathrm{me} 3)$ and two associated with repressed genes (H3K9me3 and $\mathrm{H} 3 \mathrm{~K} 27 \mathrm{me} 3)$.

Before setting out to assess epigenetic states in embryos, we first determined gene expression profiles in unfertilized eggs and in MBT embryos (3 biological replicates each) using customdesigned Agilent microarrays. The data revealed maternal vasa, pou5f1, otx1b, bactin2 and at a lower level, tert transcripts (Fig. 2A). In contrast, sox3, nnr and klf4 transcripts were strongly upregulated at MBT, from very low levels in the egg, while sox2 was slightly upregulated and remained expressed at low level (Fig. 2A). Reverse transcription (RT)-PCR data confirmed transcript detection at the $\mathrm{MBT}^{+}$stage (Fig. 2B).

The genes examined could be categorized into four groups according to their histone PTM profile on promoters (Fig. 3). A first group consisting of pou5f1, sox3, nnr, tert, nes and the housekeeping gene bactin2 were enriched in $\mathrm{H} 3 \mathrm{~K} 9 \mathrm{ac}, \mathrm{H} 4 \mathrm{ac}$ and H3K4me3 with no or little repressive H3K9me3 or H3K27me3, consistent with their expression (Fig. 3A). Enrichment levels seemed to vary along the promoter regions assessed, in a genespecific manner. These differences were not due to varying quantitative (q)PCR efficiencies because opposite patterns could be observed for the same genomic fragments associated with other PTMs (e.g., H3K4me3 on pou5f1 or nnr, Fig. 3A). A second group harbored activating PTMs (H3K9ac, H4ac, H3K4me3) and repressing $\mathrm{H} 3 \mathrm{~K} 27 \mathrm{me} 3$ (sox2, klf4; Fig. 3B). A third PTM profile was detected on otx $1 b$, with essentially no acetylation but high levels of $\mathrm{H} 3 \mathrm{~K} 4 \mathrm{me} 3$ and $\mathrm{H} 3 \mathrm{~K} 27 \mathrm{me} 3$ (Fig. 3C). This combination 
was reminiscent of the co-enrichment of these marks on so-called "bivalent" promoters in embryonic stem (ES) cells (Bernstein et al., 2006; Pan et al., 2007). A fourth profile was observed on vasa, which harbored, in addition to activating PTMs, H3K27me3 together with H3K9me3 (Fig. 3D). Thus, a subset of expressed developmentally-regulated genes in $\mathrm{MBT}^{+}$stage embryos is acetylated on $\mathrm{H} 3 \mathrm{~K} 9$ and $\mathrm{H} 4$ with no trimethylation on $\mathrm{H} 3 \mathrm{~K} 9$ or H3K27, while another subset appears to harbor a combination of activating and repressing PTMs. All promoters are enriched in $\mathrm{H} 3 \mathrm{~K} 4 \mathrm{me} 3$, corroborating the view that $\mathrm{H} 3 \mathrm{~K} 4 \mathrm{me} 3$ marks most promoters, at least in undifferentiated cells (Zhao et al., 2007), including in developing zebrafish (Wardle et al., 2006), regardless of expression.

A

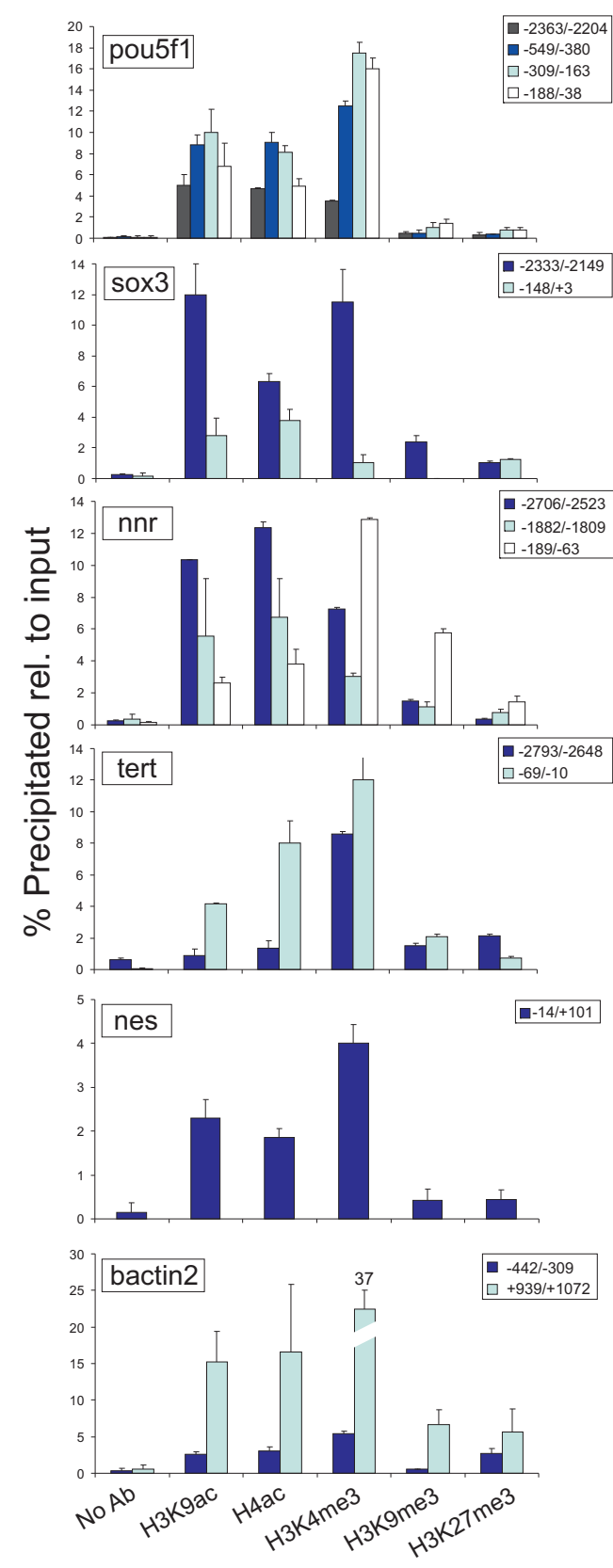

\section{B}
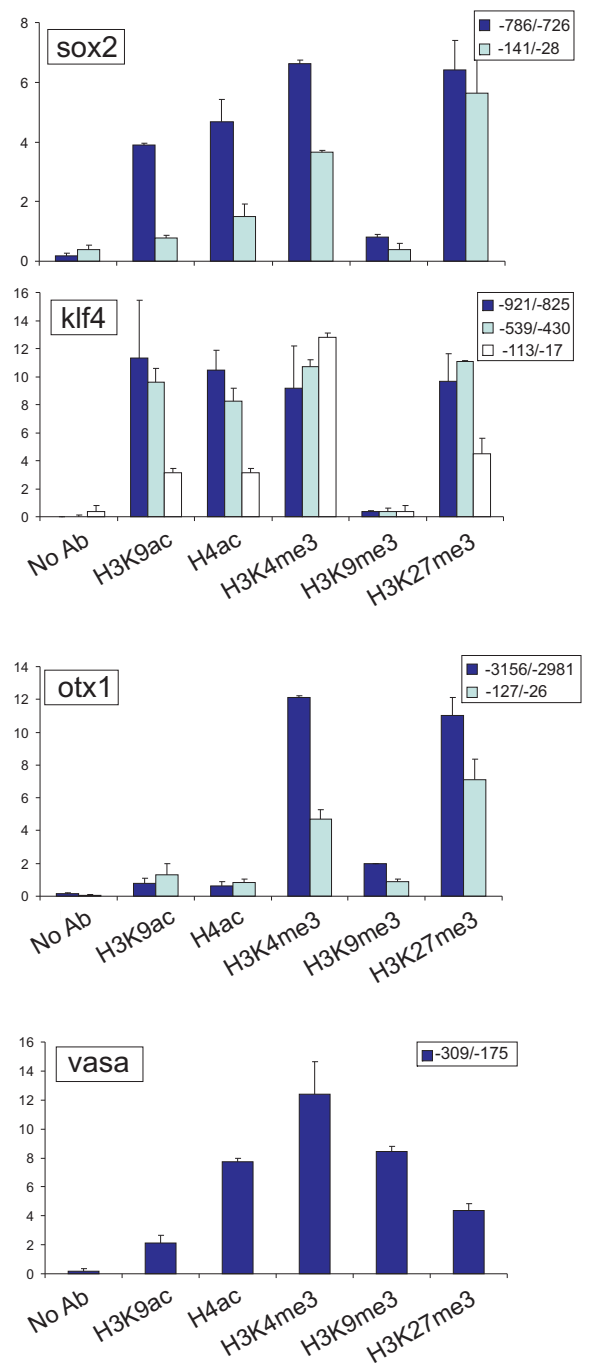

Fig. 3. Histone modification patterns on developmentally-regulated genes in $\mathrm{MBT}^{+}$ embryos. (A-D) Histone PTMs were ChIPed from $\mathrm{MBT}^{+}$embryo chromatin and their occupancy on promoters of indicated genes was determined by $q P C R$. "No Ab" refers to a noantibody (bead-only) control ChIP.

\section{Embryonic genes are associated with repressing histone}

How specific to embryos were the histone PTM profiles detected was determined bynexamining the zebrafish fibroblast cell line, ZF4 (Driever and Rangini, 1993). All embryonic gene promoters showed strong deacetylation on $\mathrm{H} 3 \mathrm{~K} 9$ and $\mathrm{H} 4$ relative to (Sup lack of, or barely detectable, expression of these in ZF4 cells, retained acetylated epitopes, illustrating these somatic cells.

The distinct histone PTM profiles detected in embryos and in ZF4 cells may reflect an embryonic vs. differentiated state, or alternatively, the fact that ZF4 is an immortalized cultured cell line with altered epigenetic states, as opposed to being a primary somatic cell type. To distinguish between these possibilities, we determined histone PTM profiles in adult zebrafish uncultured muscle biopsies. ChIP data indicate that pou5f1, klf4, sox2 and vasa,nnone of which were expressed in muscle (Fig. 4A), displayed PTMs of repressed genes, namely no $\mathrm{H} 3 \mathrm{~K} 9 \mathrm{ac}$ or $\mathrm{H} 4 \mathrm{ac}$, but rather, enrichment in $\mathrm{H} 3 \mathrm{~K} 4 \mathrm{me} 3$ in combination with trimethylated $\mathrm{H} 3 \mathrm{~K} 9$ and H3K27 (Fig. 4B). In contrast, the expressed bactin2 and $\mathrm{mlc} 2$ (myosin light chain 2, also called myl10; a myogenic marker) promoters were occupied by H3K9ac and H4ac (Fig. 4C). Interestingly, the mlc2 promoter was also strongly enriched in H3K27me3, suggesting a mosaic epigenetic state with acetylated histones on certain alleles and trimethylated H3K27 on others. Alternatively, this finding suggests a mosaic $m / c 2$ expression pattern in muscle tissue, as anticipated from heterogeneous cell types in a muscle biopsy. The distinct histone PTM enrichment patterns identified in embryos and in muscle, therefore, respectively reflect the epigenetic states of embryonic cells vs. adult somatic tissue.

\section{Heterochromatinization of embry- onic genes in primary cell cul- tures derived from embryos}

To ensure that differences in PTM profiles between embryos and ZF4 cells were not due to fish strain (and thus genotypic) differences, we iso- 
A

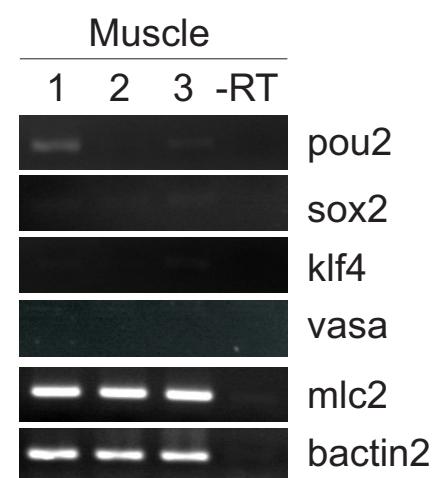

Fig. 4. Embryonic genes are repressed and trimethylated on H3K9 and H3K27 in somatic tissue. (A) RT-PCR analysis of expression of indicated genes in muscle biopsies from three different fish; -RT, PCR without reverse transcription. (B,C) ChIP analysis of indicated histone modifications on the promoters of indicated genes. In (C), insets highlight H3K9ac and H4ac occupancy on mlc2 and bactin2.
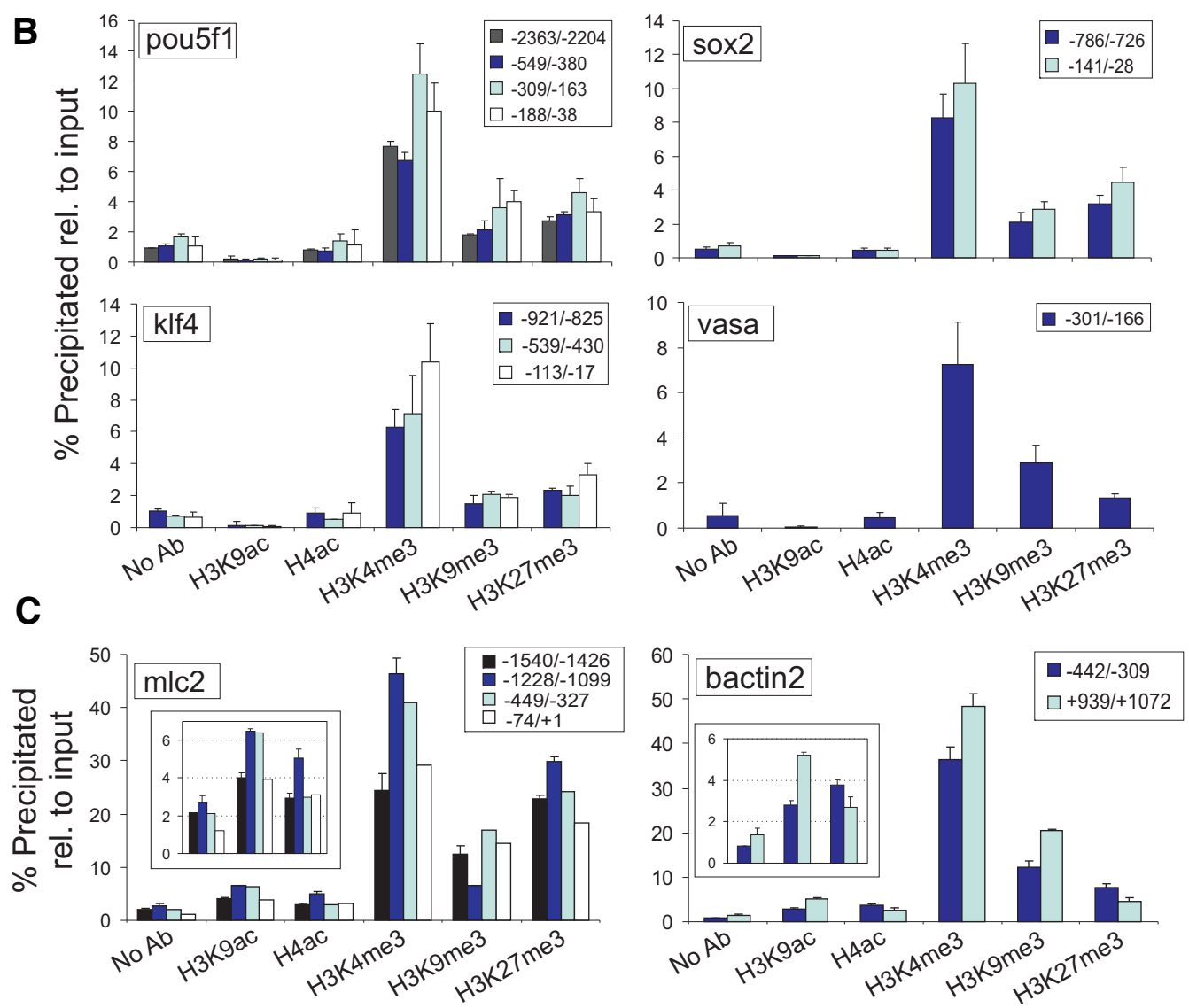

lated individual cells from $\mathrm{MBT}^{+}$embryos and seeded them in 6well plates for $24 \mathrm{~h}$ before gene expression and ChIP analysis. As in ZF4 cells, embryonic genes were deacetylated on $\mathrm{H} 3 \mathrm{~K} 9$ and $\mathrm{H} 4$ relative to H3K4me3 (Fig. 5A). Deacetylation was accompanied by enrichment in $\mathrm{H} 3 \mathrm{~K} 9$ me3 and $\mathrm{H} 3 \mathrm{~K} 27$ me3, including on promoters not harboring these marks in the embryo (pou5f1, sox3, nnr, nes). Moreover, promoters enriched in H3K27me3 in embryos acquired trimethylation on H3K9 (sox2, klf4, otx1b). bactin2 retained acetylated marks, consistent with its expression in embryo-derived cells (Fig. $5 \mathrm{~A}, \mathrm{~B}$ ).

These results are indicative of heterochromatinization of embryonic genes upon culture of embryo-derived cells under conditions which promote spontaneous differentiation. Indeed, all genes (except bactin2) were repressed upon culture (Fig. 5B). The detection of transcripts on day 1 of culture likely reflected the persistence of embryonic mRNAs rather than actual transcription, which would not be permitted by H3K9 and H3K27 hypertrimethylation. Disappearance of these mRNAs over time supported this view (Fig. 5B, Day 5), and ChIP data on day 5 cultures confirmed the stability of heterochromatinization taking place on the embryonic genes (data not shown).

\section{Mosaic klf4 expression in embryos correlates with co-detec- tion of H3K4me3 and H3K27me3 on the promoter}

The co-detection of H3K4me3 and H3K27me3 on a number of embryonic gene promoters suggests that these PTMs may be coenriched on these promoters in a manner reminiscent of the trimethylated H3K4/H3K27 "bivalency" of developmentally-regulated promoters in'embryonic stem cells (Bernstein et al., 2006). Such bivalency would be assessed by sequential ChIP of H3K4me3 and $\mathrm{H} 3 \mathrm{~K} 27 \mathrm{me} 3$ and vice versa. However, such sequential ChIPs from $\mathrm{MBT}^{+}$embryo chromatin to assess co-occupancy on sox2, $k l f 4$ and ot $x 1 b$ was inconclusive (data not shown).

H3K4/K27me3 co-detection could also reflect mosaic expression of these genes in the embryo at the $\mathrm{MBT}^{+}$stage. Mosaic gene expression is a hallmark of embryonic development in notably mouse (Rossant and Tam, 2009) and zebrafish (Sprague et al., 2003; Lunde et al., 2004; Sprague et al., 2006) and may be at the origin of lineage specification. Whole-mount in situ hybridization of $\mathrm{MBT}^{+}$embryos showed that sox 3 was ubiquitously expressed (Fig. 6), consistent with the activating histone PTMs detected on the promoter. otx $1 b$ mRNA was also detected in all blastomeres despite its enrichment in H3K4me3 and H3K27me3 (Fig. 6); nevertheless this was consistent with otx $1 b$ being maternally expressed. In contrast to sox3 however, klf4 displayed a striking mosaic expression pattern between blastomeres (Fig. 6). We infer from these results that $\mathrm{H} 3 \mathrm{~K} 4 / \mathrm{K} 27 \mathrm{me} 3 \mathrm{co}$-detection by ChIP on $k l f 4$ reflects a mosaic expression pattern, although this may not be the only explanation (see Discussion).

\section{Embryonic genes are CpG unmethylated in embryos, but strongly methylated in fibroblasts}

To provide additional insight on epigenetic states of embryonic genes in $\mathrm{MBT}^{+}$embryos, we next assessed DNA methylation at 
A
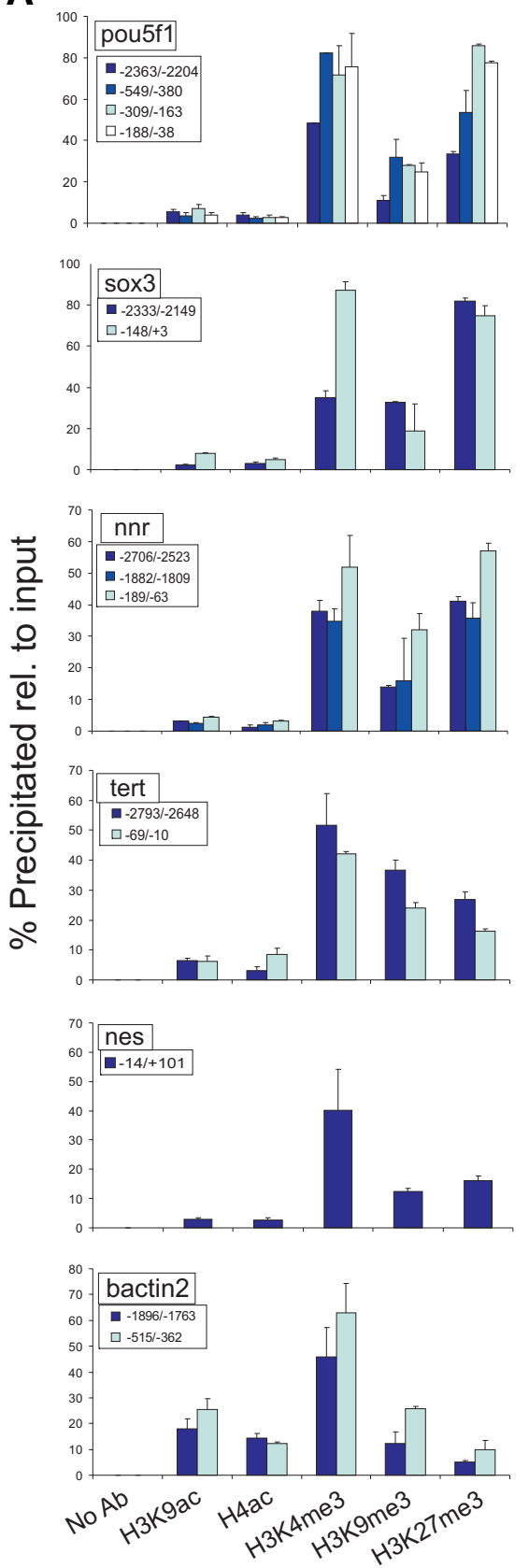

B
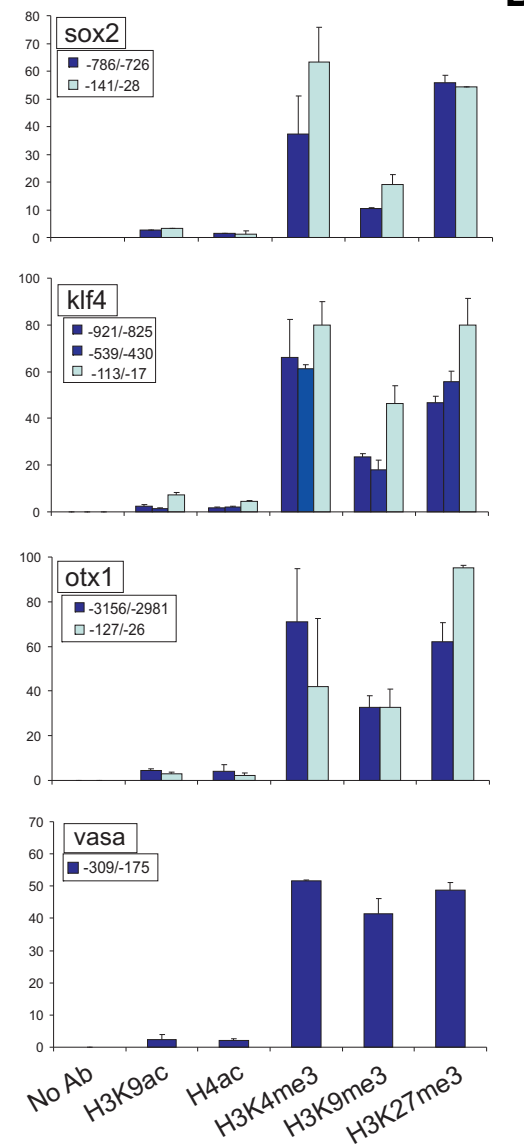

Fig. 5. Histone modification and gene expression patterns in cultured embryo-derived cells. (A) Cells isolated from $\mathrm{MBT}^{+}$embryos were cultured for $24 \mathrm{~h}$ and histone PTMs examined as in Figure 3. (B) RT-PCR analysis of gene expression in embryo-derived cells cultured for 1, 2 or 5 days. -RT, PCR without reverse transcription on RNA isolated from Day 1 cultured cells.

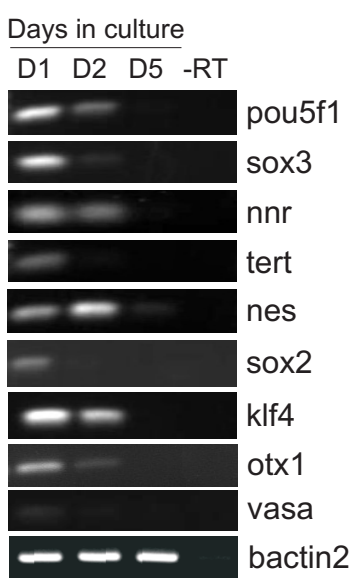

providing a chromatin structure permissive for gene expression.

\section{Discussion}

\section{Complex histone PTM enrichment profiles on promoters of early developmentally-regulated genes}

We have mapped by ChIP histone PTMs on promoters of early zebrafish developmentallyregulated genes shortly after activation of the embryonic genome. We identify four histone PTM profiles over a background of unmethylated DNA: (i) $\mathrm{H} 3 \mathrm{~K} 4 \mathrm{me} 3$ and acetylated $\mathrm{H} 3 \mathrm{~K} 9$ and $\mathrm{H} 4$ with no or barely detectable H3K9me3 and H3K27me3 (pou5f1, sox3, nnr, nes); (ii) H3K4me3, H3K9ac and $\mathrm{H} 4 \mathrm{ac}$ together with repressive H3K27me3 (sox2, klf4); (iii) H3K4me3 and H3K27me3 without significant acetylation (otx1b), a profile reminiscent of the so-called "bivalent" state of repressed or weakly expressed developmentally regulated gene promoters in embryonic stem cells (Azuara et al., 2006; Bernstein et al., 2006); and (iv) $\mathrm{H} 3 \mathrm{~K} 4 \mathrm{me} 3$, acetylated $\mathrm{H} 3 \mathrm{~K} 9$ and $\mathrm{H} 4$, and trimethylated $\mathrm{H} 3 \mathrm{~K} 9$ and $\mathrm{H} 3 \mathrm{~K} 27$ (vasa). The diversity of these profiles indicates no simple relationship between promoter occupancy by activating or repressing histone PTMs and the presence of

single-base resolution by bisulfite genomic sequencing. We found that embryonic promoters (sox2, pou $5 f 1, k l f 4$, sox3, ot $x 1 b$ and vasa) were unmethylated, whereas tert was strongly methylated (Fig. 7). In contrast, in ZF4 cells, pou5f1, sox3, klf4, ot $x 1 b$ and vasa were strongly methylated (Fig. 7), in agreement with their repressed state. Furthermore, tert was also strongly methylated except for two CpGs at position -1157 and -1150 relative to the transcription start site (TSS) (Fig. 7), suggesting that these $\mathrm{CpG}$ s are important for telomerase expression in ZF4 cells (Supplementary Fig. 1B). sox2 was, as in embryos, largely unmethylated in ZF4, which could be explained by its location within a $\mathrm{CpG}$ island. These results indicate that embryonic gene promoters are unmethylated at this stage of development, transcripts in the zebrafish embryo at this critical stage of development. This view extends recent findings at the single gene level (O'Neill et al., 2006; Vermilyea et al., 2009) and on a genomescale (Dahl et al., 2010) in mouse embryos.

\section{Epigenetic states of embryonic genes in relation to develop- mental dynamics}

The complexity of histone PTM profiles reported here reflects the diversity of developmental programs within the embryo, such that not all embryonic genes are expressed in all blastomeres (Rossant and Tam, 2009; Chan et al., 2009). The salt-and-pepper distribution of klf4 transcripts illustrates the differential programming of individual cells and would account for the apparent co- 

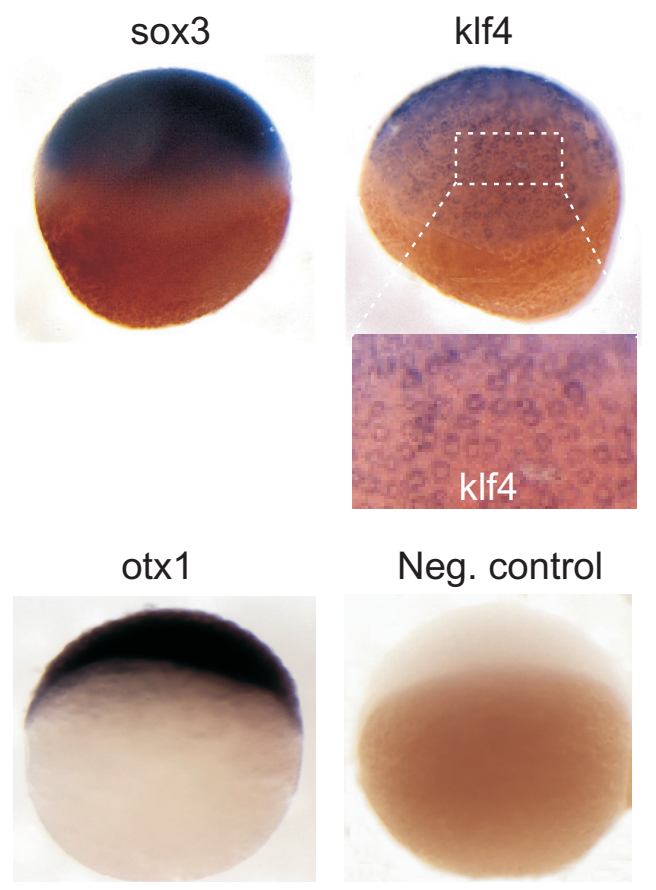

enrichment of klf4 in H3K4me3, H3K9ac - and H3K27me3. klf4 may be enriched in $\mathrm{H} 3 \mathrm{~K} 27 \mathrm{me} 3$ (conceivably with $\mathrm{K} 4 \mathrm{me} 3$ ) only in cells not expressing the gene, while expressing cells display H3K4me3 (without K27me3).

This however does not exclude the possibility of true co-
Fig. 6. Whole-mount in situ hybridization analysis of expression of indicated genes in $\mathbf{M B T}^{+}$stage embryos. Enlargement of klf4 hybridization pattern (boxed area) shows mosaic expression between blastomeres. A negative control otx $1 \mathrm{~b}$ hybridization using a sense ot $\times 1 \mathrm{~b}$ probe is also shown.

enrichment in $\mathrm{H} 3 \mathrm{~K} 4 / \mathrm{K} 27$ me3 within a single cell (albeit possibly on different alleles) or on a single klf4 promoter sequence, in cells not expressing klf4. Based on genome-wide data from mouse and human embryonic stem cells (Azuara et al., 2006; Bernstein et al., 2006; Pan et al., 2007), as well as in hematopoietic progenitors (Cui et al., 2009), such H3K4/K27me3 "bivalent" state would predict that non-klf4 expressing cells are programmed for later upregulation of the gene. Indeed, klf4 is strongly upregulated post-MBT (Sprague et al., 2003; Sprague et al., 2006; O'Boyle et al., 2007). Interestingly, recent genome-wide H3K4me3 and H3K27me3 promoter mapping data in mouse embryos reveals co-enrichment of these marks on developmentally-regulated genes (Dahl et al., 2010). Collectively, these and our findings support the view of transcriptional "priming" of developmentally important genes by H3K4/K27me3 co-enrichment (Azuara et al., 2006; Bernstein et al., 2006). Later in development, klf4 may be upregulated in more cells or in all cells, an event that would be associated with H3K27 demethylation. Demethylation of H3K27me3 may de-repress developmentally important genes not only during embryonic stem cell differentiation (Azuara et al., 2006; Bernstein et al., 2006) but also during development. Alternatively, klf4 may remain mosaically expressed post-MBT and

A
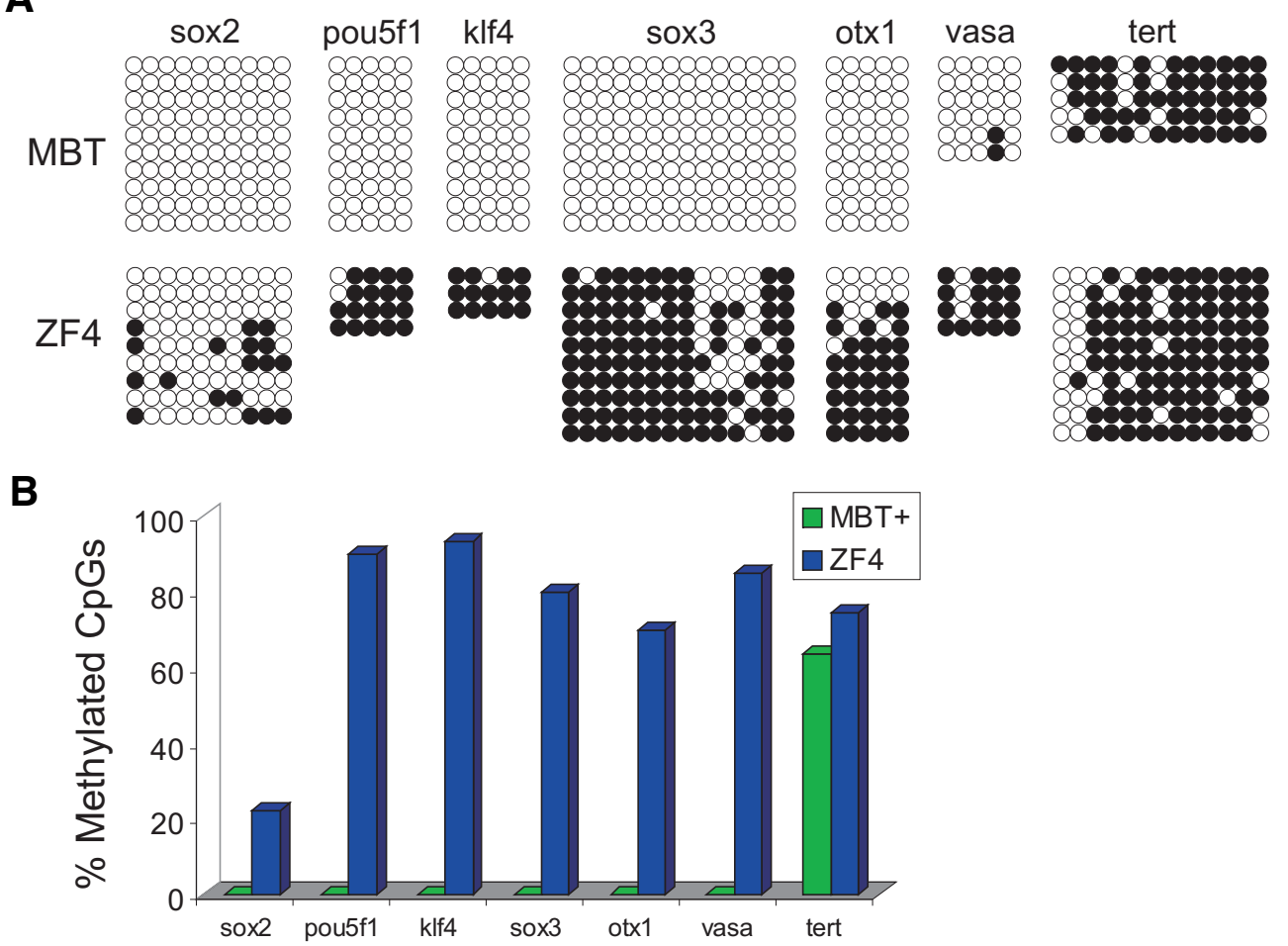

Fig. 7. Embryonic genes are DNA unmethylated in $\mathbf{M B T}^{+}$stage embryos. (A) Bisulfite sequencing analysis of $C p G$ methylation in the promoter of indicated genes in MBT+ embryos and in ZF4 cells. Each circle represents one CpG and methylation is shown in the 5' to 3' orientation (left to right); (०) unmethylated $C p G ;(\bullet)$ methylated $C p G$. Three to ten sequenced clones of PCR products are shown to provide quantification (rows). (B) Percentage of methylated CpGs for each gene, determined from data in (A). 
retain $\mathrm{H} 3 \mathrm{~K} 27 \mathrm{me} 3$ in a subset of blastomeres.

sox3 and $n n r$, which are not maternally expressed, are upregulated at the MBT and at least for sox3, ubiquitously in the embryo. The absence of H3K27me3 on these promoters argues that this transcriptional brake has been released to enable expression throughout the embryo in subsequent stages. Moreover, sox2 transcripts are only moderately detected at the mid-late MBT, consistent with moderate $\mathrm{H} 3 \mathrm{~K} 9$ and $\mathrm{H} 4$ acetylation on the promoter. Further, histone PTM profiles of pou5f1 and tert would be consistent with some transcription level taking place in the embryo, while the sox2 profile suggests a repressive effect of H3K27me3 despite promoter occupancy by acetylated H3K9 and $\mathrm{H} 4$; indeed, sox2 is upregulated post-MBT (Mathavan et al., 2005; Sprague et al., 2006) (our unpublished data), i.e. later than klf4, sox3 or $n n r$.

\section{DNA hypomethylation on developmentally-regulated pro- moters reflects an underlying transcriptionally permissive state}

A transcriptionally permissive chromatin organization of developmentally-regulated genes in the embryo is supported by the unmethylated state of DNA in the promoters examined. CpG unmethylated promoters are not necessarily expressed (Weber et al., 2007), in consistency with our findings; nonetheless, the absence of DNA methylation is likely to provide a flexible chromatin configuration prone to timely regulation by other mechanisms (e.g., histone PTMs or transcription factor binding). This relationship between promoter DNA methylation and potential for gene expression is reminiscent of that in embryonic or mesenchymal stem cells: whereas strong CpG methylation is transcriptionally restrictive, no or weak methylation constitutes a permissive state (Azuara et al., 2006; Sørensen et al., 2009).

In contrast to the embryo, all genes except sox2, embedded in a CpG island presumably protected from methylation (Weber et al., 2007), are hypermethylated in ZF4 fibroblasts. This is in accordance with their transcriptional repression and reflects the differentiated state of these cells (Driever and Rangini, 1993). Interestingly however, CpG -1157 in the tert promoter remains unmethylated while $\mathrm{CpG}-1150$ is demethylated in ZF4 cells. CpG -1150 is flanked by two binding sites for elongation factor 2 (E2F) (www.cbrc.jp/research/db/TFSEARCH.html), a transcription factor implicated in cell cycle regulation (Chen et al., 2009). CpG demethylation at this site may enable E2F binding and induction of telomerase expression in this immortalized cell line. This suggests that tert expression is regulated by DNA methylation.

Differentiation events taking place during lineage specification result in cell type-specific gene expression patterns and epigenetic states. The dynamics of histone PTMs during zebrafish development remains to be determined. Asymmetry of genomewide promoter distribution of, in particular, H3K27me3 between the inner cell mass and trophectoderm (the first two developmental lineages) in mouse blastocysts suggests that gene expression patterns can be promptly modulated in response to developmental decisions (Dahl et al., 2010). Rapid development of zebrafish embryos relative to mammals requires fast and accurate mechanisms of histone deposition and removal, presumably from a pool of maternally stored histones which can be modified, as recently shown in Xenopus embryos (Shechter et al., 2009).

\section{Materials and Methods}

\section{Embryos and cells \\ Mid-late blastula stage embryos}

Mid-late blastula (referred here to as $\mathrm{MBT}^{+}$) $\mathrm{AB}$ strain zebrafish embryos were collected at $3.5 \mathrm{~h}$ post-fertilization. For RNA isolation, embryos were immediately snap-frozen in ethanol/dry ice. For ChIP, embryos were processed as described below.

\section{Unfertilized eggs}

Unfertilized eggs were collected immediately after spawning, prior to fertilization, washed, snap-frozen in ethanol/dry ice and stored at $-80^{\circ} \mathrm{C}$ prior to RNA extraction.

\section{$\mathrm{MBT}^{+}$embryo-derived cells}

$\mathrm{MBT}^{+}$embryos $(\mathrm{n}=500-1000)$ in system water were transferred to a sterile $100 \mu \mathrm{m}$ sieve (BD Biosciences; www.bdbiosciences.com). Embryos were rinsed twice for $10 \mathrm{sec}$ in a well containing system water, washed once in $70 \%$ ethanol for $15 \mathrm{sec}$, twice in water for $30 \mathrm{sec}$, and bleached 3 times in $0.025 \%$ chlorine with 10 -sec washing steps in LDF medium (Leibowitz's L15/Delbecco's MEM/Hams's F12 in proportions of 50:35:15). Embryos were treated with $1 \mathrm{mg} / \mathrm{ml}$ pronase for $15 \mathrm{~min}$ in Hanks solution (Invitrogen; www.invitrogen.com), trypsinized for $5 \mathrm{~min}$ in TryLE Express (Invitrogen) and gently pipetted with a transfer pipette while inside the sieve to assist in dechorionation and cell dissociation. Dissociated cells were collected in a Petri dish, leaving chorions in the sieve. Cells were transferred to a tube of fetal bovine serum using a new transfer pipette and sedimented at $300 \mathrm{~g}$ for $5 \mathrm{~min}$. Cells were then seeded at $10^{5}$ cells per well in 6-well plates (Nunc, delta-surface; www.nuncbrand.com) in growth medium (LDF supplemented with $2.5 \%$ fetal calf serum, $5 \%$ zebrafish embryo extract (Fan et al., 2004) at $25 \mu \mathrm{g} /$ $\mathrm{ml}$ protein, $1 \%$ heat inactivated SeaGrow trout serum (East Coast Biologics; www.eastcoastbio.com), $10 \mu \mathrm{g} / \mathrm{ml}$ bovine insulin, $50 \mathrm{ng} / \mathrm{ml}$ bovine FGF, $50 \mathrm{ng} / \mathrm{ml} \mathrm{EGF}$ and $31.5 \%$ conditioned medium from RTS34 cells). RTS34 cells were cultured in $70 \%$ Leibowits's L 15 media $/ 30 \%$ fetal calf serum and antibiotics (Fan et al., 2006). Cells were cultured at $28^{\circ} \mathrm{C}$ for $24 \mathrm{~h}$ and those forming aggregates were transferred to new wells for further culture.

\section{ZF4 cells}

The ZF4 zebrafish fibroblastoid cell line (ATCC, CRL-2050; www.atcc.org) was cultured as described (Driever and Rangini, 1993).

\section{ChIP antibodies}

Antibodies used were anti-H3K4me3 (Abcam Ab8580-100, www.abcam.com; or Diagenode pAb-003-050; www.diagenode.com), anti-H3K9me3 (Diagenode pAb-056-050), anti-H3K27me3 (Abcam Ab60052-100; Upstate 07-449, www.upstate.com; or Millipore 07-449, www.millipore.com), anti-H3K9ac (Upstate 06-942), and anti-H4ac (Upstate 06-866).

\section{Chromatin preparation}

$\mathrm{MBT}^{+}$embryos

Chromatin from $\mathrm{MBT}^{+}$embryos was prepared as described (Lindeman et al., 2009). In short, 500 embryos in water were transferred to a 5-ml syringe, water was replaced with PBS/20 mM Na-butyrate and embryos forced through a 21 gauge needle into a $1.5 \mathrm{ml}$ tube. Isolated cells were cross-linked with $1 \%$ formaldehyde in PBS/butyrate for $8 \mathrm{~min}$, the reaction stopped with $125 \mathrm{mM}$ glycine, cells washed in PBS/butyrate, sedimented and snap-frozen in ethanol-dry ice. Cells were lysed in $250 \mu$ lysis buffer (50 mM Tris- $\mathrm{HCl}, \mathrm{pH} 8.0,10 \mathrm{mM}$ EDTA, 1\% SDS, protease inhibitors and $20 \mathrm{mM}$ Na-butyrate) and sonicated in two lots of $125 \mu \mathrm{l}$ for $6 \times 30$ sec on ice using a Sartorius Labsonic $\mathrm{M}$ sonicator with a 3-mm diameter probe at 
setting 0.5 cycle and $30 \%$ power (Sartorius AG; www.sartorius.com). Fragmented chromatin ( 400 bp fragments on average, determined by agarose gel electrophoresis) was diluted in RIPA ChIP buffer (10 mM Tris$\mathrm{HCl}, \mathrm{pH} 7.5,140 \mathrm{mM} \mathrm{NaCl}, 1 \mathrm{mM}$ EDTA, 0.5 mM EGTA, 1\% Triton X-100, $0.1 \%$ SDS, $0.1 \%$ Na-deoxycholate, protease inhibitors, $20 \mathrm{mM} \mathrm{Na}$ butyrate) to $0.2 \mathrm{U} \mathrm{A}_{260}$ before immunoprecipitation.

\section{Muscle biopsy}

Muscle biopsies $\left(2 \mathrm{~mm}^{3}\right.$ ) from adult fish ( $\mathrm{n}=2$ for ChIP; $\mathrm{n}=3$ for RT$\mathrm{PCR}$ ) were snap-frozen in liquid nitrogen. Upon thawing, biopsies were crosslinked for $8 \mathrm{~min}$ in $1 \%$ formaldehyde in PBS $/ 20 \mathrm{mM}$ Na-butyrate and washed 3 times in PBS/butyrate. After adding $300 \mu \mathrm{llysis}$ buffer, samples were sonicated for $5 \times 30 \mathrm{sec}$ and sedimented at $10,000 \mathrm{~g}$. The supernatant was removed to a clean tube. Lysis buffer was added to the pellet up to $300 \mu \mathrm{l}$, the sample sonicated for another $5 \times 30 \mathrm{sec}$, sedimented and the supernatant pooled with the first one. The pooled chromatin fraction (containing 400 bp average fragments) was diluted in RIPA ChIP buffer to $0.2 \cup \mathrm{A}_{260}$.

\section{ZF4 cells}

ZF4 cells $\left(15 \times 10^{6}\right)$ were crosslinked in suspension for 8 min in 1\% formaldehyde in PBS/butyrate and the reaction stopped with $125 \mathrm{mM}$ glycine. Cells were lysed in $300 \mu$ lysis buffer and sonicated $8 \times 30 \mathrm{sec}$ to an average of $400 \mathrm{bp}$. Chromatin was diluted in RIPA ChIP buffer before immunoprecipitation.

\section{Embryo-derived cells}

Cells which formed aggregates on day 1 of culture were collected and transferred to a $50 \mathrm{ml}$ tube containing LDF medium and $20 \mathrm{mM} \mathrm{Na}$ butyrate. Cells were sedimented, transferred to a $0.6 \mathrm{ml}$ tube and crosslinked for $8 \mathrm{~min}$ as above. After quenching and washing, cells were lysed and sonicated for $5 \times 30 \mathrm{sec}$. Chromatin was diluted in RIPA ChIP buffer to $0.2 \cup A_{260}$ before immunoprecipitation.

\section{Chromatin immunoprecipitation and PCR analysis}

Chromatin at concentrations indicated above, in $100 \mu$ I RIPA ChIP buffer/butyrate, was mixed with $10 \mu \mathrm{l}$ antibody-Dynabeads Protein A (Invitrogen) complexes overnight at $4^{\circ} \mathrm{C}$. Immune complexes were washed three times in RIPA and once in Tris-EDTA (TE) buffer. The cross-link was reversed and DNA eluted in a single step for $2 \mathrm{~h}$ at $68^{\circ} \mathrm{C}$ in $150 \mu \mathrm{l}$ of 20 $\mathrm{mM}$ Tris- $\mathrm{HCl}, \mathrm{pH} 7.5,5 \mathrm{mM}$ EDTA, $20 \mathrm{mM}$ butyrate, $50 \mathrm{mM} \mathrm{NaCl}, 1 \%$ SDS and $50 \mu \mathrm{g} / \mathrm{ml}$ proteinase $\mathrm{K}$. Eluted DNA was purified by phenol-chloroform isoamylalcohol extraction and ethanol precipitation and dissolved in TE buffer or MilliQ $\mathrm{H}_{2} \mathrm{O}$. ChIP DNA was amplified using the Whole Genome Amplification WGA4 kit (Sigma-Aldrich; www.sigma.com) using only 10 amplification cycles. Amplification products were cleaned up using the QiaQuick PCR Purification Kit (Qiagen), eluted in $30 \mu \mathrm{ITE}$ and diluted further to $150 \mu \mathrm{l}$ in TE. For all ChIPs, $5 \mu \mathrm{l}$ DNA was used for quantitative (q)PCR. ChIPs were done from at least four independent chromatin preparations per histone PTM.

ChIP DNA was analyzed by duplicate qPCR on a MyiQ Real-time PCR Detection System using IQ SYBR ${ }^{\circledR}$ Green (BioRad; www.biorad.com). ChIP PCR primers are listed in Supplementary Table 1. PCR conditions were $95^{\circ} \mathrm{C}$ for $3 \mathrm{~min}$ and 40 cycles of $95^{\circ} \mathrm{C}$ for $30 \mathrm{sec}, 60^{\circ} \mathrm{C}$ for $30 \mathrm{sec}$ and $72^{\circ} \mathrm{C}$ for $30 \mathrm{sec}$. ChIP Data are presented as mean \pm SD percent precipitated DNA relative to input.

\section{Bisulfite sequencing}

Genomic DNA was purified from $\mathrm{MBT}^{+}$embryos and ZF4 cells by double phenol-chloroform extraction and ethanol precipitation, and bisulfite-treated using MethylEasy ${ }^{\mathrm{TM}}$ (Human Genetic Signatures; www.geneticsignatures.com) as described (Noer et al., 2006). Converted DNA was amplified by PCR using primers designed with Methprimer (www.urogene.org/methprimer/index1.html) and positioned relative to the transcription start site (TSS; www.ensembl.org/Danio_rerio/) as shown in Supplementary Table 2. PCR conditions were $95^{\circ} \mathrm{C}$ for $7 \mathrm{~min}$ and 40 cycles of $95^{\circ} \mathrm{C}$ for $1 \mathrm{~min}, 54^{\circ} \mathrm{C}$ for $2 \mathrm{~min}$ and $72^{\circ} \mathrm{C}$ for $2 \mathrm{~min}$, followed by $10 \mathrm{~min}$ at $72^{\circ} \mathrm{C}$. PCR products were cloned into $E$. coli by TOPO TA cloning and sequenced.

\section{RNA isolation}

Unfertilized eggs and $\mathrm{MBT}^{+}$embryos were snap-frozen as described above and kept at $-80^{\circ} \mathrm{C}$. RNA was prepared from batches of 100 embryos. These were crushed in a mortar with liquid nitrogen, $2 \mathrm{ml}$ Trizol (Invitrogen) was added and the content was transferred to a $15-\mathrm{ml}$ tube and incubated for $5 \mathrm{~min}$ at room temperature. Chloroform $(400 \mu \mathrm{l})$ was added and embryos were shaken by hand for $15 \mathrm{sec}$ and further incubated for 2-3 $\mathrm{min}$. The lysate was centrifuged $\left(10,000 \mathrm{~g}, 10 \mathrm{~min}, 4^{\circ} \mathrm{C}\right)$, the upper phase was transferred to a new tube, $1 \mu \mathrm{l}$ glycogen added and RNA was precipitated with $1 \mathrm{ml}$ isopropanol for $10 \mathrm{~min}$ at room temperature before centrifugation as above. The pellet was washed with $75 \%$ ice-cold ethanol and stored at $-80^{\circ} \mathrm{C}$ or dissolved for DNase treatment and clean-up using the RNeasy Kit (Qiagen). For embryo-derived and ZF4 cells, $\sim 10^{6}$ snapfrozen cells were suspended in $2 \mathrm{ml}$ Trizol, pipetted 2-3 times and incubated for $5 \mathrm{~min}$ at room temperature. Chloroform $(400 \mu \mathrm{l})$ was added, cells were shaken for $15 \mathrm{sec}$, incubated for 2-3 min, aliquoted into two 1.5$\mathrm{ml}$ tubes and sedimented as above. The rest of the procedure was as above. RNA samples were cleaned up, DNase I-treated and RNA was stored at $-80^{\circ} \mathrm{C}$ until use for microarray processing or RT-PCR.

\section{Reverse-transcription-PCR}

RT-PCR was performed from $0.5 \mu \mathrm{g}$ total RNA (Qiagen RNeasy; www.qiagen.com), using the Iscript cDNA synthesis kit (BioRad). PCR conditions were $95^{\circ} \mathrm{C}$ for $3 \mathrm{~min}$ and 35 cycles of $95^{\circ} \mathrm{C}$ for $30 \mathrm{sec}, 60^{\circ} \mathrm{C}$ for $30 \mathrm{sec}$ and $72^{\circ} \mathrm{C}$ for $30 \mathrm{sec}$. RT-PCR primers used are listed in Supplementary Table 3. Products were resolved by agarose gel electrophoresis and stained with ethidium bromide.

\section{Microarray analysis}

Microarray techniques were according to Agilent's One-Color Microarray-Based Gene Expression Analysis (Quick Amp Labeling) manual Version 5.7 (www.agilent.com). Briefly, $\sim 400 \mathrm{ng}$ total RNA and spike-in RNA were used to prepare cDNA and subsequently Cy3-labeled cRNA. Labeled cRNA was fragmented prior to hybridization. Arrays were prehybridized, hybridized at $65^{\circ} \mathrm{C}$ for $\sim 17 \mathrm{~h}$, and washed as per Agilent's protocol. The arrays used contained $44 \mathrm{~K}$ probes representing all known genes and one probe for each UniGene clusters (non-redundant). Arrays also contained 153 different negative control probes scattered throughout. Array format was $44 \mathrm{Kx} 4$ and was custom-designed by Agilent for this study.

Arrays were scanned using an Agilent DNA Microarray Scanner at 5 $\mu \mathrm{m}$ resolution. Using the 16-bit tif images generated, feature extraction was performed using Feature Extraction Software 9.5.3 (Agilent) with background detrend (FeatNCRange, LoPass) and Multiplicative Detrend. Processed signals from feature extraction were imported into the $R$ environment (http://cran.r-project.org/). Data were normalized using quantile normalization (Bolstad et al., 2003). This improved correlation slightly, to $0.95-0.99$ between biological replicates ( $n=3$ for unfertilized eggs; $n=3$ for embryos). Genes of interest were extracted from the dataset. Where there were multiple probes for a single transcript or replicate probes, these were aggregated using the median value. These merged intensity values were then $\log _{2}$-transformed and mean and standard deviation calculated. Microarray expression data are available at NCBI under GEO accession number GSE20137.

\section{Whole-mount in situ hybridization}

In situ hybridization was performed using digoxygenin (DIG)-labeled riboprobes as described (Korzh et al., 1998). In short, antisense and negative control sense probes were synthesized by in vitro transcription using as templates linearized plasmids with the sequence of interest, 
DIG-labeled ribonucleotides (Roche; www.roche.com) and the appropriate RNA polymerase (Ambion; www.ambion.com). Products were purified using the RNeasy Mini Kit (Qiagen). Embryos collected at $3.5 \mathrm{~h}$ postfertilization were dechorionated, fixed overnight in $4 \%$ paraformaldehyde/ PBS and prehybridized overnight at $68^{\circ} \mathrm{C}$ in hybridization buffer $(50 \%$ formamide, $5 x$ SSC, $50 \mathrm{mg} / \mathrm{ml}$ heparin, $500 \mathrm{mg} / \mathrm{ml}$ tRNA, $0.1 \%$ Tween20). Hybridization was done in hybridization buffer containing $50 \mathrm{ng}$ to 100 ng probe overnight at $68^{\circ} \mathrm{C}$. Embryos were washed at $68^{\circ} \mathrm{C}$ for $15 \mathrm{~min}$ in hybridization wash solution (1x HWS; $50 \%$ formamide, $5 x$ SSC, $0.1 \%$ Tween-20), 15 min in $75 \%$ HWS/25\% 2x SSC, 15 min in 50\% HWS/50\% $2 x \mathrm{SSC}, 15 \mathrm{~min}$ in $25 \% \mathrm{HWS} / 75 \%$ 2x SSC, $15 \mathrm{~min}$ in $2 x \mathrm{SSC}$, and twice $30 \mathrm{~min}$ in $0.2 x$ SSC. For antibody detection, embryos were incubated for $1 \mathrm{~h}$ in $2 \%$ blocking reagent (Roche) in maleic acid buffer $(0.15 \mathrm{M}$ maleic acid, $0.1 \mathrm{M} \mathrm{NaCl}, \mathrm{pH} 7.5$ ), and incubated overnight at $4^{\circ} \mathrm{C}$ with preadsorbed anti-DIG-AP antiserum (Roche) at a 1:5,000 dilution in $2 \%$ blocking reagent in maleic acid buffer. Embryos were washed 6 times $15 \mathrm{~min}$ in PBS. Detection was performed in alkaline phosphatase reaction buffer (0.1 M Tris- $\mathrm{HCl}, \mathrm{pH} 9.5,50 \mathrm{mM} \mathrm{NaCl}, 0.1 \%$ Tween-20) containing Nitroblue Tetrazolium and 5-bromo, 4-chloro, 3-indolyl phosphate (Roche). After development of staining to desired intensity, embryos were washed in PBS and preserved in $4 \%$ paraformaldehyde/PBS at $4^{\circ} \mathrm{C}$.

\section{Acknowledgments}

This work was supported by funding from the Research Council of Norway to P.A. and P.C. The authors are grateful to Kristin Vekterud for expert assistance with RT-PCR and bisulfite sequencing.

\section{References}

ALESTRÖM, P., HOLTER, J.L. and NOURIZADEH-LILLABADI, R. (2006). Zebrafish in functional genomics and aquatic biomedicine. Trends Biotechnol. 24: 15-21.

AZUARA, V., PERRY, P., SAUER, S., SPIVAKOV, M., JORGENSEN, H.F., JOHN, R.M., GOUTI, M., CASANOVA, M., WARNES, G., MERKENSCHLAGER, M. and FISHER, A.G. (2006). Chromatin signatures of pluripotent cell lines. Nat. Cell Biol. 8: 532-538.

BERNSTEIN, B.E., MIKKELSEN, T.S., XIE, X., KAMAL, M., HUEBERT, D.J., CUFF, J., FRY, B., MEISSNER, A., WERNIG, M., PLATH, K., JAENISCH, R., WAGSCHAL, A., FEIL, R., SCHREIBER, S.L. and LANDER, E.S. (2006). A bivalent chromatin structure marks key developmental genes in embryonic stem cells. Cell 125: 315-326.

BOLSTAD, B.M., IRIZARRY, R.A., ASTRAND, M. and SPEED, T.P. (2003). A comparison of normalization methods for high density oligonucleotide array data based on variance and bias. Bioinformatics 19: 185-193.

CHAN, T.M., LONGABAUGH, W., BOLOURI, H., CHEN, H.L., TSENG, W.F., CHAO, C.H., JANG, T.H., LIN, Y.I., HUNG, S.C., WANG, H.D. and YUH, C.H. (2009). Developmental gene regulatory networks in the zebrafish embryo. Biochim. Biophys. Acta 1789: 279-298.

CHEN, H.Z., TSAI, S.Y. and LEONE, G. (2009). Emerging roles of E2Fs in cancer: an exit from cell cycle control. Nat. Rev. Cancer 9: 785-797.

COLLAS, P. and DAHL, J.A. (2008). Chop it, ChIP it, check it: the current status of chromatin immunoprecipitation. Front Biosci. 13: 929-943.

CUI, K., ZANG, C., ROH, T.Y., SCHONES, D.E., CHILDS, R.W., PENG, W. and ZHAO, K. (2009). Chromatin signatures in multipotent human hematopoietic stem cells indicate the fate of bivalent genes during differentiation. Cell Stem Cell 4: 80-93

DAHL, J.A., REINER, A.H., KLUNGLAND, A., WAKAYAMA, T. and COLLAS, P. (2010). Histone H3 lysine 27 methylation asymmetry on developmentallyregulated promoters distinguish the first two lineages in mouse preimplantation embryos. PLoS. ONE 5: e9150.

DRIEVER, W. and RANGINI, Z. (1993). Characterization of a cell line derived from zebrafish (Brachydanio rerio) embryos. In vitro Cell Dev. Biol. Anim. 29A: 749754.

FAN, L., ALESTROM, A., ALESTROM, P. and COLLODI, P. (2004). Production of zebrafish germline chimeras from cultured cells. Methods Mol. Biol. 254:289300.
FAN, L., MOON, J., CRODIAN, J. and COLLODI, P. (2006). Homologous recombination in zebrafish ES cells. Transgenic Res. 15: 21-30.

HART, D.O., RAHA, T., LAWSON, N.D. and GREEN, M.R. (2007). Initiation of zebrafish haematopoiesis by the TATA-box-binding protein-related factor Trf3. Nature 450: 1082-1085.

HAVIS, E., ANSELME, I. and SCHNEIDER-MAUNOURY, S. (2006). Whole embryo chromatin immunoprecipitation protocol for the in vivo study of zebrafish development. Biotechniques 40: 34, 36, 38 .

JAENISCH, R. and BIRD, A. (2003). Epigenetic regulation of gene expression: how the genome integrates intrinsic and environmental signals. Nat. Genet. 33 Suppl: 245-254.

KORZH, V., SLEPTSOVA, I., LIAO, J., HE, J. and GONG, Z. (1998). Expression of zebrafish bHLH genes ngn1 and nrd defines distinct stages of neural differentiation. Dev. Dyn. 213: 92-104.

KOUZARIDES, T. (2007). Chromatin modifications and their function. Cell 128 693-705

LEVINE, M. and DAVIDSON, E.H. (2005). Gene regulatory networks for development. Proc. Natl. Acad. Sci. USA 102: 4936-4942.

LINDEMAN, L.C., VOGT-KIELLAND, L.T., ALESTROM, P. and COLLAS, P. (2009). Fish'n ChIPs: chromatin immunoprecipitation in the zebrafish embryo. Methods Mol. Biol. 567: 75-86.

LUNDE, K., BELTING, H.G. and DRIEVER, W. (2004). Zebrafish pou5f1/pou2, homolog of mammalian Oct4, functions in the endoderm specification cascade. Curr. Biol. 14: 48-55.

MATHAVAN, S., LEE, S.G., MAK, A., MILLER, L.D., MURTHY, K.R., GOVINDARAJAN, K.R., TONG, Y., WU, Y.L., LAM, S.H., YANG, H., RUAN, Y., KORZH, V., GONG, Z., LIU, E.T. and LUFKIN, T. (2005). Transcriptome analysis of zebrafish embryogenesis using microarrays. PLoS. Genet. 1: 260276.

MORLEY, R.H., LACHANI, K., KEEFE, D., GILCHRIST, M.J., FLICEK, P., SMITH, J.C. and WARDLE, F.C. (2009). A gene regulatory network directed by zebrafish No tail accounts for its roles in mesoderm formation. Proc. Natl. Acad. Sci. USA 106: 3829-3834.

NOER, A., SøRENSEN, A.L., BOQUEST, A.C. and COLLAS, P. (2006). Stable $\mathrm{CpG}$ hypomethylation of adipogenic promoters in freshly isolated, cultured and differentiated mesenchymal stem cells from adipose tissue. Mol. Biol. Cell 17: 3543-3556.

O'BOYLE, S., BREE, R.T., MCLOUGHLIN, S., GREALY, M. and BYRNES, L. (2007). Identification of zygotic genes expressed at the midblastula transition in zebrafish. Biochem. Biophys. Res. Commun. 358: 462-468.

O'NEILL, L.P., VERMILYEA, M.D. and TURNER, B.M. (2006). Epigenetic characterization of the early embryo with a chromatin immunoprecipitation protocol applicable to small cell populations. Nat. Genet. 38: 835-841.

PAN, G., TIAN, S., NIE, J., YANG, C., RUOTTI, V., WEI, H., JONSDOTTIR, G.A., STEWART, R. and THOMSON, J.A. (2007). Whole-genome analysis of histone $\mathrm{H} 3$ lysine 4 and lysine 27 methylation in human embryonic stem cells. Cell Stem Cell 1: 299-312.

ROSSANT, J. and TAM, P.P. (2009). Blastocyst lineage formation, early embryonic asymmetries and axis patterning in the mouse. Development 136: 701-713.

SHECHTER, D., NICKLAY, J.J., CHITTA, R.K., SHABANOWITZ, J., HUNT, D.F. and ALLIS, C.D. (2009). Analysis of histones in Xenopus laevis. I. A distinct index of enriched variants and modifications exists in each cell type and is remodeled during developmental transitions. J. Biol. Chem. 284: 1064-1074.

SØRENSEN, A.L., TIMOSKAINEN, S., WEST, F.D., VEKTERUD, K., BOQUEST, A.C., ÄHRLUND-RICHTER, L., STICE, S.L. and COLLAS, P. (2009). Lineagespecific promoter DNA methylation patterns segregate adult progenitor cell types. Stem Cells Dev. (doi:10.1089/scd.2009.0309)

SPRAGUE, J., BAYRAKTAROGLU, L., CLEMENTS, D., CONLIN, T., FASHENA, D., FRAZER, K., HAENDEL, M., HOWE, D.G., MANI, P., RAMACHANDRAN, S., SCHAPER, K., SEGERDELL, E., SONG, P., SPRUNGER, B., TAYLOR, S., VAN SLYKE, C.E. and WESTERFIELD, M. (2006). The Zebrafish Information Network: the zebrafish model organism database. Nucleic Acids Res. 34: D581D585

SPRAGUE, J., CLEMENTS, D., CONLIN, T., EDWARDS, P., FRAZER, K. SCHAPER, K., SEGERDELL, E., SONG, P., SPRUNGER, B. and WESTERFIELD, M. (2003). The Zebrafish Information Network (ZFIN): the 
zebrafish model organism database. Nucleic Acids Res. 31: 241-243.

VERMILYEA, M.D., O'NEILL, L.P. and TURNER, B.M. (2009). Transcriptionindependent heritability of induced histone modifications in the mouse preimplantation embryo. PLOS. ONE 4: e6086.

WARDLE, F.C., ODOM, D.T., BELL, G.W., YUAN, B., DANFORD, T.W., WIELLETTE, E.L., HERBOLSHEIMER, E., SIVE, H.L., YOUNG, R.A. and SMITH, J.C. (2006). Zebrafish promoter microarrays identify actively transcribed embryonic genes. Genome Biol. 7: R71.
WEBER, M., HELLMANN, I., STADLER, M.B., RAMOS, L., PAABO, S., REBHAN, M. and SCHUBELER, D. (2007). Distribution, silencing potential and evolutionary impact of promoter DNA methylation in the human genome. Nat. Genet. 39: 457-466.

ZHAO, X.D., HAN, X., CHEW, J.L., LIU, J., CHIU, K.P., CHOO, A., ORLOV, Y.L., SUNG, W.K., SHAHAB, A., KUZNETSOV, V.A., BOURQUE, G., OH, S., RUAN, Y., NG, H.H. and WEI, C.L. (2007). Whole-genome mapping of histone H3 Lys4 and 27 trimethylations reveals distinct genomic compartments in human embryonic stem cells. Cell Stem Cell 1: 286-298. 